\title{
Hydrology and Hydraulics Expertise in Participatory Processes for Climate Change Adaptation in the Dutch Meuse
}

\author{
Anna Wesselink ${ }^{1}$ \\ School of Earth and Environment \\ University of Leeds \\ United Kingdom \\ Huib de Vriend \\ Faculty of Civil Engineering \& Geosciences \\ Delft University of Technology \\ The Netherlands \\ Hermjan Barneveld \\ HKV consultants \\ Lelystad \\ The Netherlands \\ Maarten Krol \\ Department Water Engineering and Management \\ Faculty of Engineering \\ University of Twente \\ The Netherlands \\ Wiebe Bijker \\ Department Technology \& Society Studies \\ Faculty of Arts and Social Sciences \\ Maastricht University \\ The Netherlands
}

\begin{abstract}
Many scientists feel that scientific outcomes are not sufficiently taken into account in policy-making. The research reported in this paper shows what happens with scientific information during such a process. In 2001 the Dutch Ministry of Transport, Public Works and Water Management commissioned their regional office in Limburg to assess how flood management objectives can be achieved in future in the Dutch Meuse valley, assuming climate change will increase peak discharges. To ensure political support, regional discussion rounds were to help assess the measures previously identified. This paper discusses the ways in which hydrological and hydraulic expertise was input, understood and used in this assessment process. Project participants as a group had no trouble contesting assumptions and outcomes. Nevertheless, water expertise was generally accepted as providing facts, once basic choices such as starting situation had been discussed and agreed. The technical constraints determined that politically unacceptable measures would have to be selected to achieve the legally binding flood management objective. As a result, no additional space will be set aside for future flood management beyond the already reserved floodplain. In this case, political arguments clearly prevail over policy objectives, with hydraulic expertise providing decisive arbitration between the two.
\end{abstract}

\footnotetext{
${ }^{1}$ Corresponding author a.wesselink@see.leeds.ac.uk. Formerly with Department of Water Engineering and Management, Faculty of Engineering, University of Twente, The Netherlands.
} 


\section{INTRODUCTION}

In the last millennium, water experts have played a large role in shaping the physique of The Netherlands. They contribute their technical knowledge, but they do not hesitate to get involved in the political debates on water management either. Of all water management issues, flood protection is the subject which, not surprisingly, attracts the most heated debates. Looking at their interventions in the national media, water experts' involvement has not guaranteed that they are always happy with the policy outcomes: they feel that their expertise is not (sufficiently) taken into account. Superficially it therefore looks as if water expertise is contested. If this is true, it can be understood at two levels. At a general level, the interventions made by water experts and the effect they achieve can be considered a normal part of the political process where different communities promote different ideas and values, or simply vie for political power. In this process powering often wins from puzzling (Flyvbjerg, 1998; Hoppe in prep.) and economic interests often trump other concerns, so it is no surprise that water experts should feel that other parties are more influential. At a more detailed level, there have been some recent shifts in the policy-making arena in the Netherlands that could give the impression of a relative decline of water experts' position as other disciplines came to the fore and got involved in what were traditionally water experts' domains. This started with the ecological turn in water management in the 1980's (Disco, 2002; Bijker, 2002; Lintsen, 2002) followed some 15 years later by a spatial turn, with the introduction of a 'landscape quality' as objective (Wesselink et al., 2007). Conversely, the policy changes mentioned above can also be conceived as a new impulse to water experts, giving them a new platform to deliver their expertise.

This apparent contradiction between less influence and a new impulse is one example of what Nowotny has called the 'dilemma of expertise': 'Expertise has never before been so indispensable, while being simultaneously so hotly contested' (Nowotny, 2003: 151-152). Whether it is the expertise itself that is contested or whether it is used as a means to argue over policy goals is the topic of this paper. However, we will not examine the national policy-making processes and their outcomes. Rather, we will look at the regional scale where policies are implemented. We will show that water expertise is indispensable and decisive, though not uncontested, in the specific case of flood management. We show that it is the skill of the expert to make sure things get done; this also means sometimes doing work they might not find necessary or do work in a way they find sub-optimal. These are the constraints imposed by the politics of the policy-making process. But first we need to clarify a few terms which we have been using without explanation so far: experts and expertise.

\section{EXPERTS AND EXPERTISE}

In the introduction, we have used the term 'water experts' without specifying who these are and why we group them into one category. In this paper, water experts are professionals whose expertise is the design and/or construction of human interventions in rivers. They work for governmental organisations, commercial consulting or constructing firms, or in academia. They are mostly civil engineers, but also include related professions such as geographers and mathematicians. We are grouping these professionals under one heading because they form a community who use the same assumptions, theories and models. The substantive scope of water experts is more limited than that of 'river studies' distinguished by Van Hemert (2004), as the latter include ecology.

According to the dictionary definition an expert is 'one who has gained skill from experience [...]; one whose special knowledge or skill causes him to be regarded as an authority; a specialist' (Oxford English Dictionary online 2008). In this definition it is clear that knowledge is not the only attribute experts have. While knowledge is related to 'information acquired by study or research; ascertained truths, facts, or principles' (Oxford English Dictionary online 2008), expertise includes the skills needed to use knowledge in a specific context. According to Collins \& Evans (2002) expertise involves the ability to translate to experts in different domains, and the ability to discriminate between knowledge claims judged from the socio-political context. For expertise to be useful in policy-making 
processes, the ability to translate to non-experts is at least as important as the ability to translate to other experts. In addition to the substantive expertise discussed by Collins \& Evans (2002), political expertise, i.e. dealing with power relations between relevant social groups, and procedural expertise, i.e. dealing with project planning and facilitation of meetings, are necessary for a decision-making process to be successful (Leeuwis \& Van den Ban, 2004: 180). A degree of sensitivity to political and procedural issues is therefore useful for experts, making their expertise to be effective in a decisionmaking context.

Employing the term 'expertise' instead of 'knowledge' has several advantages. First, it emphasises that knowledge is used in certain ways and that choices have to be made on how to use it: the use of knowledge is not neutral but ultimately depends on purpose and context and 'can never be reduced to the purely scientific and purely technical' (Nowotny, 2003: 152). Second, and related to the previous point, expertise is defined in a particular context which requires the interpretation of available knowledge as well as making informed guesses about the not available knowledge. 'When acting as experts, scientists do not respond to questions that they have chosen [...] they are under instant and intense pressure to respond to a crisis in decision-making, when neither all necessary knowledge nor sufficient information is available, uncertainties abound and yet action must be taken' (Nowotny, 2003: 152). Third, there is no necessary association between conventionally certified scientific and technical experts and expertise: so-called lay people can also have expertise in the field of interest. Collins and Evans show that the term 'lay expertise' is a contradiction in terms, for 'the dictionary definition of 'layman' includes the sentiment 'someone who is not an expert' (Collins \& Evans, 2002: 238). Expertise, then, can reside with 'those who have not been recognised in the granting of certificates' (Collins \& Evans, 2002: 251). The question of whose expertise is to be recognised, translated and incorporated into action is a political one, and results in the above mentioned 'dilemma of expertise': the simultaneous contestation of and need for expertise. We will now show how this dilemma was played out in the project 'Integrated Assessment of the River Meuse' (IVM).

\section{THE MEUSE AND THE MODEL}

The Meuse river originates in northern France, but its main catchment area is situated in the Ardennes massif in eastern Belgium. Its catchment area of approx. 33,500 $\mathrm{km}^{2}$ includes parts of France, Luxemburg, Belgium, Germany and the Netherlands (Table 1 and Figure 1). The Meuse is a rainfall river with floods occurring mainly in the winter months; the average precipitation varies from 1400 $\mathrm{mm} /$ year in the upper reaches to $750 \mathrm{~mm} /$ year in the lowlands. The spatial distribution patterns of rainfall in the Meuse basin clearly reflect the differences in altitude, which rises to $500 \mathrm{~m}$ a.s.l in the Ardennes (Pfister et al. 2004). The mean discharge is approx. $221 \mathrm{~m}^{3} / \mathrm{s}$ at its mouth but due to its rapid reaction to precipitation there is a relatively large variability in both the mean annual and in the annual maximum discharge (Figure 2). The longest discharge record is available at Borgharen, where the Meuse enters the Netherlands: discharge measurements started there in 1911 (Table 2 and Table 3).

\begin{tabular}{|c|c|c|c|c|}
\hline country & $\begin{array}{c}\text { main } \\
\text { tributaries }\end{array}$ & $\begin{array}{c}\text { total area } \\
\left(\mathbf{k m}^{2}\right)\end{array}$ & $\begin{array}{c}\text { distance } \\
\text { from } \\
\text { source } \\
(\mathbf{k m})^{1}\end{array}$ & $\begin{array}{c}\text { average } \\
\text { discharge }\left(\mathbf{m}^{3} / \mathbf{s}\right) \\
\text { (location) }\end{array}$ \\
\hline France & Chiers & 8,525 & 485 & (Chooz) 135 \\
\hline $\begin{array}{l}\text { Belgium \& } \\
\text { Luxemburg }\end{array}$ & $\begin{array}{c}\text { Semois, } \\
\text { Sambre, Ourthe }\end{array}$ & 13,250 & 631 & (Borgharen) 221 \\
\hline $\begin{array}{l}\text { Germany } \\
\text { the Netherlands } \\
\text { total }\end{array}$ & $\begin{array}{l}\text { Ruhr, Niers } \\
\text { Geul, Dommel }\end{array}$ & $\begin{array}{r}4,315 \\
7,470 \\
33,560\end{array}$ & $\begin{array}{c}-- \\
900\end{array}$ & (Lith) 311 \\
\hline
\end{tabular}

Note: ${ }^{1}$ at the national border in the main channel

Table 1 Physical characteristics of the Meuse (Goudriaan et al. 2003; Berger 2002) 


\begin{tabular}{cc}
\hline & discharge $\left(\mathbf{m}^{3} / \mathbf{s}\right)$ \\
minimum $($ year $)\left(\mathrm{m}^{3} / \mathrm{s}\right)$ & $477(1972)$ \\
average $\left(\mathrm{m}^{3} / \mathrm{s}\right)$ & 1506 \\
maximum $($ year $)\left(\mathrm{m}^{3} / \mathrm{s}\right)$ & $3175(1926)$ \\
\hline
\end{tabular}

Table 2 Peak flows of the Meuse at Borgharen 1911-1999 (Gerretsen 2009)

\begin{tabular}{cc}
\hline return period $(\mathbf{y r})$ & discharge $\left(\mathbf{m}^{\mathbf{3}} / \mathbf{s}\right)$ \\
50 & 2710 \\
100 & 2955 \\
250 & 3278 \\
1250 & 3800 \\
\hline
\end{tabular}

Table 3 Estimates of low probability peaks at Borgharen (Ministerie van V\&W 2001)

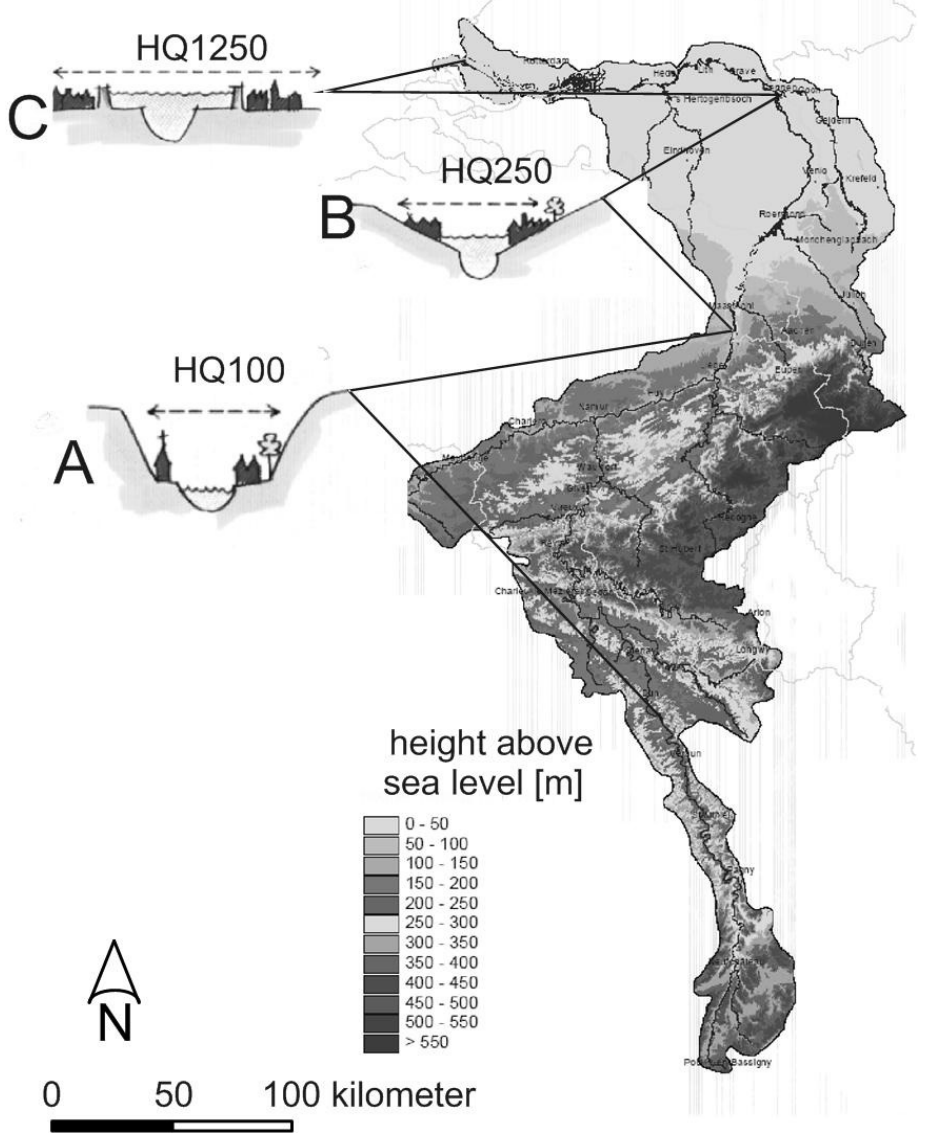

Figure 1 Catchment area of the river Meuse with tributaries, topography and typical cross sections. $\mathrm{HQ}=$ Return periods of the design discharge (Reuber et al. 2005) 


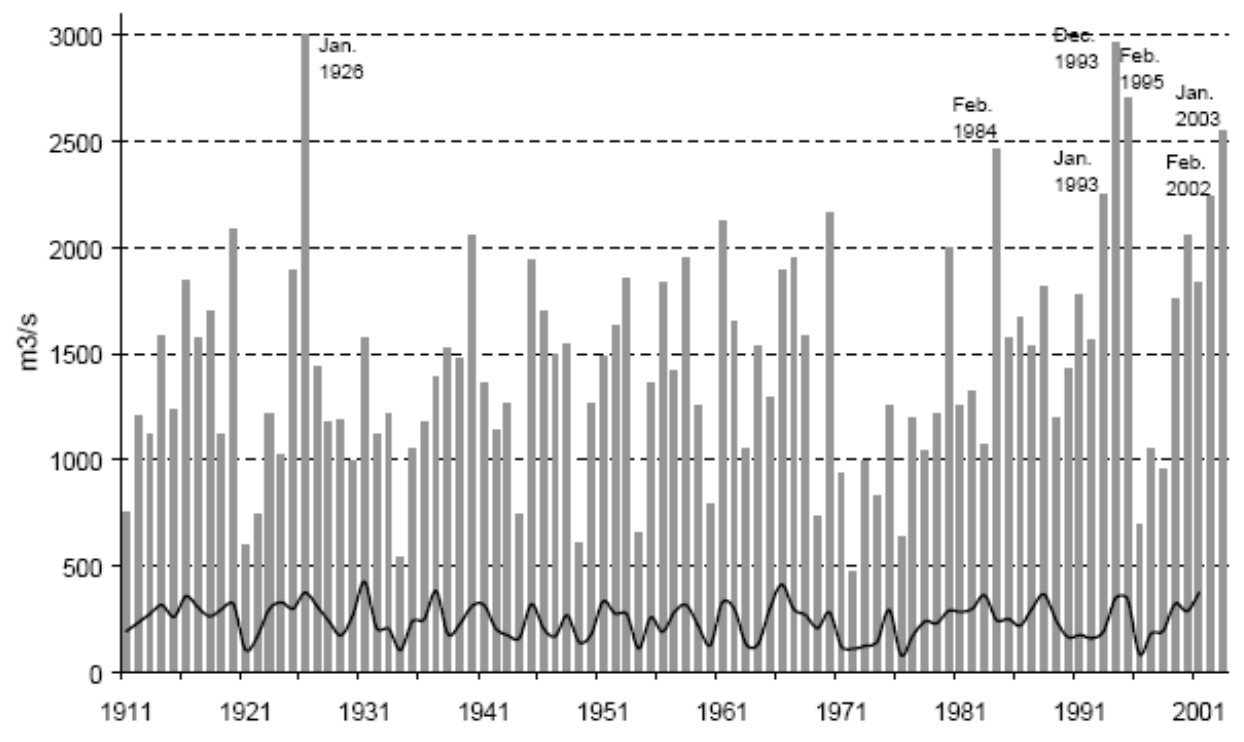

Figure 2 Maximum daily discharge in hydrological years (Oct-Sept) (Goudriaan et al. 2003)

Like most of the Netherlands, the natural floodplain of the downstream part of the Meuse river, stretch $\mathrm{C}$ in Figure 1, is protected from flooding by dikes. This system of flood protection has developed over the course of the last millennium (e.g. Bijker, 1993; TeBrake, 2002). In the last 150 years the area regularly flooded has reduced with about $60 \%$. However, in the southern part of the Meuse, stretch B in Figure 1, only recently (after flooding in 1995) low embankments were constructed to protect the populated centres from flooding; historically the river could flow freely onto the floodplain. As the Netherlands is the most densely populated country in the European Community, pressure on available space is high, and increasing with economic growth. To some politicians and developers the remaining flood plains seem nice empty spaces waiting to be built on. In an effort to control developments, planning regulations are strict. Only recently the legal status of the floodplain in the southern part of the Meuse has been changed to align with that of the downstream floodplains, to become a no-go area for development (Staatsblad, 2006).

The flood protection levels are also laid down in the Law on Water Defence Systems. The required height of river dikes is calculated from the design discharge, the probability of exceedancefor which was set at 1/1250 per year for the downstream part (stretch $C$ ) and 1/250 per year for the upstream part (stretch B). The protection level in section B proved to be only 1/50 per year and the project Maaswerken was initiated to realise the desired protection level, which will be completed by 2015 . Further upstream in Belgium and France, a probability of exceedance 1/100 per year is more usual in flood protection (stretch A in Figure 1). By law design water levels are recalculated every 5 years from available discharge data, after which adjustments are made to dike levels and/or river bed or flood plain to guarantee the same protection level (e.g. Ministerie van V\&W, 2001). The calculation of design water levels is generally done with a detailed two-dimensional model WAQUA (http://www.waqua.nl/). For feasibility studies and morphological analyses a one-dimensional model based on the SOBEK-code (http://delftsoftware.wldelft.nl/) is also available. This one-dimensional model was used in the IVM project discussed here. Itis a spatially 1D numerical model based on the Saint-Venant Equations for unsteady flow, integrated over parts of the cross-section (main channel, flood-conveying floodplains, storage areas). It uses a simplified 1-D schematisation of the river layout with 1 value of the dependent variables (discharge, water depth) in each part of the cross-section. In the schematisation used in the IVM project the Dutch part of the Meuse is divided into 23 sections and 
described by 461 cross-sectional profiles, each with a different shape and hydraulic parameters. A typical Chezy value is $45 \mathrm{~m}^{0.5} \mathrm{~s}^{-1}$ (section Zandmaas2) (Ministerie van V\&W, 2003b).

\section{PLANNING FOR FUTURE FLOOD MANAGEMENT IN THE MEUSE}

In the second half of the 1990's climate change predictions triggered the Dutch Ministry of Transport, Public Works and Water Management to investigate how increased probabilities of high river floods could be accommodated in the Meuse floodplain. Hydrologists estimated the increase of the 1/1250 per year discharge at $20 \%$ by the year 2050 , from $3800 \mathrm{~m}^{3} / \mathrm{s}$ to $4600 \mathrm{~m}^{3} / \mathrm{s}$ (Wit et al., 2001). For the $1 / 250$ per year discharge the same relative increase of $20 \%$ was assumed, increasing this discharge from 3275 to $3950 \mathrm{~m}^{3} / \mathrm{s}$ (Table 4). The corresponding water level rise, for the current river channel geometry, would be $0.75 \mathrm{~m}$ on average (Figure 4).

\begin{tabular}{cccccc}
\hline year & $\mathbf{2 0 0 0}$ & $\mathbf{2 0 5 0}$ & $\mathbf{2 0 5 0}$ & $\mathbf{2 0 5 0}$ & $\mathbf{2 1 0 0}$ \\
beenario & & +0.5 & +1.0 & +2.0 & +4.0 \\
worst case & average case \\
temperature $\left({ }^{\circ} \mathrm{C}\right)$ & & $+3 \%$ & $+6 \%$ & $+12 \%$ & $+24 \%$ \\
winter precipitation & $350-425$ & & & & \\
$(\mathrm{~mm})$ & & +0.10 & +0.25 & +0.45 & +110 \\
$\begin{array}{c}\text { sea level rise }(\mathrm{m}) \\
\text { design discharge }\end{array}$ & 3800 & 4000 & 4200 & 4600 & 5300 \\
$\begin{array}{c}\mathrm{P}=1 / 1250)\left(\mathrm{m}^{3} / \mathrm{s}\right) \\
\text { design discharge }\end{array}$ & 3275 & 3600 & 3800 & 3950 & 4600 \\
$(\mathrm{P}=1 / 250)\left(\mathrm{m}^{3} / \mathrm{s}\right)$ & & & & & \\
\hline
\end{tabular}

Table 4 Estimates of benchmark data for the river Meuse in the future(Reuber et al. 2006)

National policy aims to accommodate any increased discharge by so-called 'spatial measures' in the flood plain instead of the traditional dike strengthening, as the former is thought to be more robust in the long term. This policy was named 'Room for the River' (Bruijn \& Klijn, 2001; Wiering \& Driessen, 2001; Reuss, 2002). Suitable measures are: parallel river channels, deepening or widening of the river bed and/or flood plain, removal of obstacles or relocation of dikes and levees (Figure 3), and temporary storage reservoirs. All of these require the reservation of land for flood protection measures, while a simple increase in dike height is usually cheaper and requires less space. Especially in the southern part of the Meuse valley the new approach was proving difficult to sell. Inhabitants of this section of the river, where there are no dikes, are accustomed to having no restrictions on land use, contrary to downstream sections where dikes provide visual separations between the river and built-up areas. Moreover, the controversial proposals and drawn-out procedures in the on-going Maaswerken flood management project have upset many (Tol et al., 2003; Van der Meulen et al., 2006). Inhabitants thus argue for upstream measures, but extensive studies have shown that only large scale water storage in upstream areas would have a significant effect on these rare discharges. Such large-scale measures, however, are politically unacceptable and outside the territory of the Netherlands (Goudriaan et al. 2004). Second best are improved storage facilities in the upstream floodplains; however, due to the steep valleys the storage capacity is limited. Altogether this meant that the measures needed to deal with increased design discharges needed to be found in the Netherlands. 

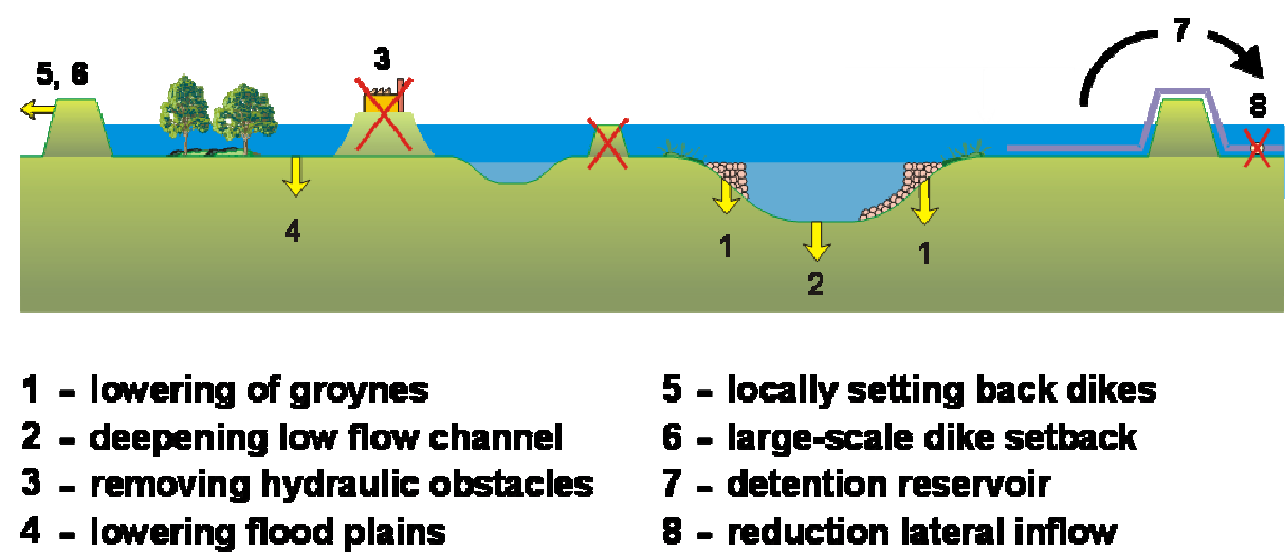

Figure 3 Room for the River measures (Ministerie van V\&W 2003)

In this context of resistance, it was the task of the project 'Integrated Assessment of the River Meuse' (IVM) to find a selection of flood management measures that were both politically acceptable at regional and national scale, and would ensure the legal level of flood protection in the future (after realisation of the Maaswerken) when climate change would cause increased peak flows. The required space for the selected measures would have to be set aside and protected from developments. In a preliminary study, a total of 160 possible individual measures was identified on the $230 \mathrm{~km}$ stretch of the Dutch Meuse. This study followed a similar investigation for the Rhine and its branches (Silva, 2001; Tol et al., 2003; Kors, 2004). The target water level reduction is depicted in Figure 4. In this Figure, the horizontal line light blue indicates the water level at the current design discharge $(\mathrm{Q}=3800$ $\mathrm{m}^{3} / \mathrm{s}$ ); this is the water level which should be achieved at least by implementing measures. The solid red line depicts the relative water level in the future in the worst case scenario $\left(\mathrm{Q}=4600 \mathrm{~m}^{3} / \mathrm{s}\right)$; the fainter red lines the water levels at 4200 and $4000 \mathrm{~m}^{3} / \mathrm{s}$ (Table 4). Implementing all 160 measures would reduce the water level well below the target horizontal line. In Figure 4 graph A presents the reduction in water level for the package which is best from a landscape point of view, and graph B the water level effects for a package which is best from a river engineering point of view. It is clear that there is little difference in the resulting water level reduction. The meaning of the other elements in the Figure will be explained below (Figure 5).

The regional division Limburg of the Ministry of Transport, Public Works and Water Management was in charge of the project. Various ministries and administrative and political bodies were involved, and political anchorage was ensured by a supervisory board comprising regional politicians and administrators, but the main events where water expertise was discussed were the project group and the regional workshops. The project group consisted of senior civil servants from the provinces, the relevant ministries and the water boards. It provided politically informed advice to the project team, thus bridging the gap between experts and politicians. In addition to the project group meetings, regional workshops were organised to get more feedback from the local level, both on the need to do something and on what needed to be done. All municipalities were invited to participate in these workshops, in addition to NGOs and citizens' groups. The main objectives of the workshops were to explain the problem, i.e. the need to prepare for increased discharge, to hear participants' opinion about future flood management, to collect ideas for new flood protection measures, and to obtain an assessment of the measures, as proposed in experts' analyses. Some of the civil servants participating in the project group also attended these regional workshops, as well as operational staff of the Ministry of Transport, Public Works and Water Management. Because of the considerable overlap between the workshops' participants and the project group members, the debates on water expertise in these gatherings were similar and influencing each other. We will therefore refer to members of the project group and participants in the workshops as 'participants' when more specification is not needed. 
Through the discussions in the project group and the working groups, civil servants working for local and regional administrations were kept informed of, and to some extent contributed to, experts' investigations. The potential solutions and the evaluation methods were mostly chosen by the experts involved in the project, but there was some degree of influence by local and regional civil servants. It was in this process of influencing substantive choices that water expertise was contested.

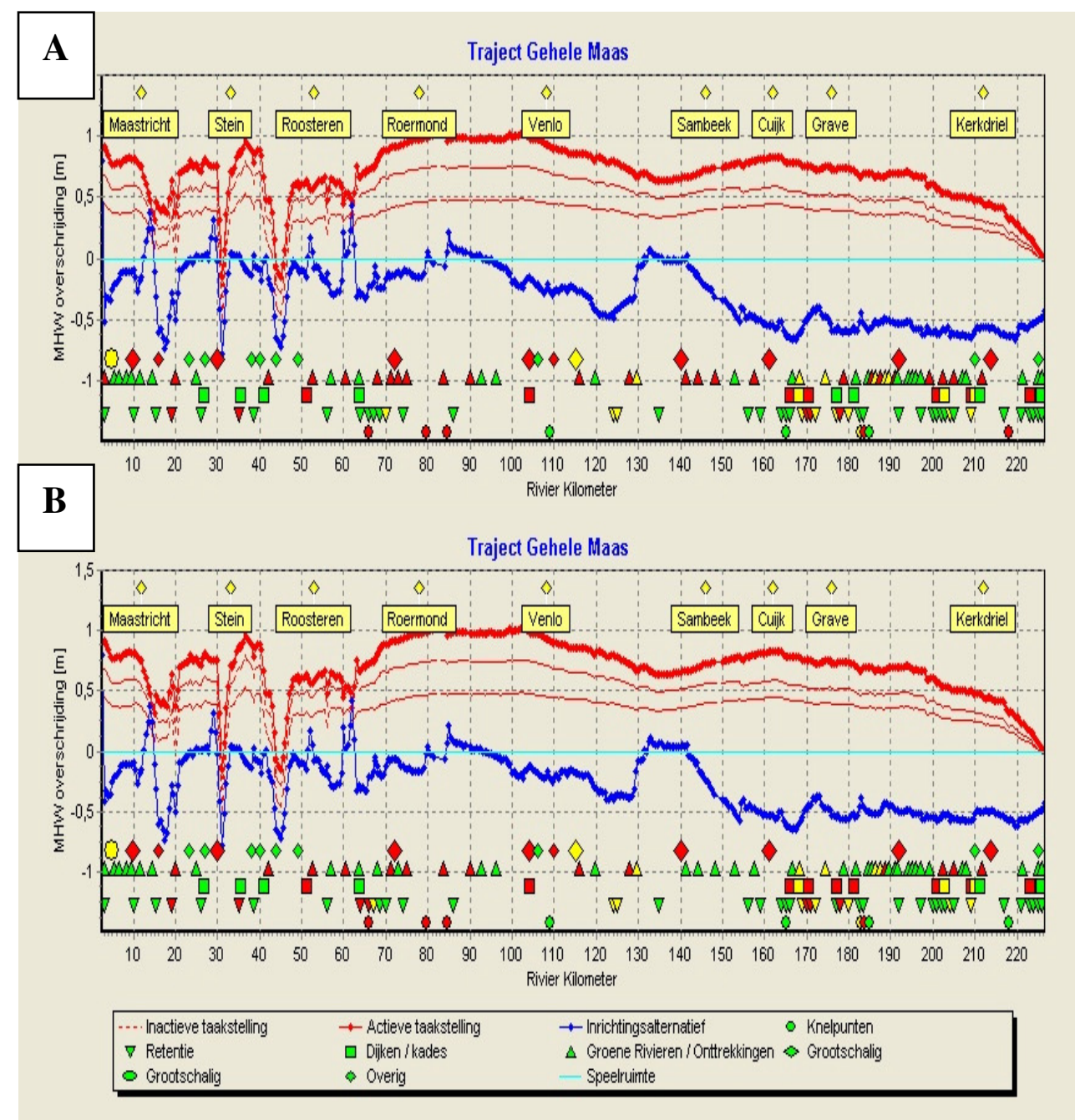

Figure 4 Hydraulic task after climate change for the Meuse after implementation of the Maaswerken (thick red line) and (thick blue line) water level effects of the package which is best from a landscape point of view (A) and package which is best from a river engineering point of view (B)

\section{WATER EXPERTISE CONTESTED}

The verification of water level targets was the water experts' core activity in IVM (Wesselink et al., 2006). Essentially, a higher discharge in the future would cause water levels to rise. IVM's objective was to select engineering measures in the floodplain that would create space for the extra water ('room for the river') and thereby draw down the water level to (or below) the present design level. The water experts' main tool was a hydraulic model. Such a model calculates the water level along the river from the river discharge and the physical layout of the river (cross section profile, slope of the river bed, 
surface roughness of the river bed and floodplains, presence of obstacles). In IVM the river discharge used in the computations was the one expected to occur in extreme circumstances in the future, more precisely: the legal flood protection design discharge expected for 2050. In the downstream part of the Meuse this is the discharge with a probability of exceedance of 1/1250 per year and in the upstream part this is $1 / 250$ per year discharge. Both the design discharge and the hydraulic model were contested during the project group meetings and the regional workshops.

\section{ESTIMATE OF DESIGN DISCHARGE}

The experts' estimate of the design discharge was challenged in several ways. The participants pointed out the uncertainty of the calculations as such (limited data, statistics and predictions of future climate). The experts responded by producing a note which explained the method and assumptions behind the outcomes. The note stressed that the estimates are indeed uncertain, but some best guess figure had to be chosen as a working hypothesis. This conclusion was generally accepted. A subsequent change of target, whereby the planning horizon was changed from 2050 to 2100 but the design discharge remained the same at $4600 \mathrm{~m}^{3} / \mathrm{s}$, was not questioned. Since the design discharge did not change, this adjustment did not change the selection of measures, which is what the participants were focussing on.

A more persistent challenge came from some participants who felt that the possibility of upstream measures had not been investigated fully and that this should be done before considering more work in the Dutch Meuse. Upstream measures would reduce the design discharge and possibly eliminate the need for extra measures and therefore the need for IVM. The experts responded to this suggestion with a study on upstream flood alleviation possibilities in Belgium and France. They drew the preliminary conclusion that only big flood retention reservoirs would be effective, but from a socio-political point of view it seemed unlikely that they would ever be realised. However, this was not sufficient to appease the challengers. The heated debates on whether or not to accept the need for IVM continued, with other participants arguing that negotiations within the Meuse catchment had so far not yielded any concrete results and the Netherlands could not afford to be dependent and wait for others to take action. In the end, the challengers decided to go along with the project as long as their concerns were transmitted to the Deputy Minister for Water Management. The Deputy Minister was urged to intensify diplomatic negotiations.

The design discharge was challenged in a third manner, too. What if the region could agree that it wished to allow for a higher flood risk than laid down in the law, rather than accept more flood defence measures? Although the project team felt that these ideas would not be acceptable to the Deputy Minister, they asked the experts to also consider the possibility of two lower design discharges of 4200 and $4400 \mathrm{~m}^{3} / \mathrm{s}$ (return periods of 500 and 800 respectively for the worst case scenario 2050). This showed what would be needed if the design discharge did not increase by $20 \%$ but less (10 and $15 \%$ respectively), that is if a combined approach to flood management would be chosen with technical measures up to a certain level and adaptation and financial compensation beyond this level. At the same time, these calculations showed how a stepwise approach might be implemented in time.

Finally, participants in the southern part of the river did not agree to use a probability of exceedance of the design discharge of 1/1250 per year for their selection of measures, because in their region the legal flood protection level was only $1 / 250$. Not only did this mean that they would do more than necessary, they also thought it would mean that they would provide storage in their area preventing flooding downstream which they felt was an uneven distribution of responsibilities. The dispute was finally settled when the outcome of hydraulic calculations showed that the retention measures taken in the upstream areas had only limited effect for the downstream area, and vice versa. It was concluded that the upstream area could not alleviate flooding problems downstream so any measures would be selected purely for the benefit of the region where the measure was implemented. This made the task more acceptable.

By challenging the design discharge figures, the participants expressed first of all a general doubt about the need to prepare for increased discharges in future by reserving land for flood measures at 
present. As a municipal administrator said: 'They need to show with facts that it is really necessary before we will accept more engineering in our area'. However, the participants were prepared to suspend their general doubt and go along with the exercise set by IVM. Nevertheless, through the continuing challenges to the design discharge they tried to reduce the magnitude of the task, i.e. limit the number of measures they need to select. Altogether this seems to indicate that it would be very difficult to obtain cooperation for the implementation of flood protection measures to accommodate a design discharge that was not based on actual observations. This opinion was voiced literally by one project group member who reported that his organisation would block any proposal that was not based on observed discharges, saying that the effects of climate change were too unpredictable to warrant concrete measures in the present time. This opinion is in effect supported by the present law: the design discharge is set for the foreseeable future so opponents would not find it difficult to challenge any concrete proposal based on estimates of future discharges in court.

We believe that the main reason why the participants went along with the assumed design discharge was the exploratory character of the study. As a civil servant said: 'This is not as serious as they like us to believe. In view of the political difficulties [...] a binding decision will not be taken.' The participants knew that many studies and consultations would be necessary before the diggers could move in, providing ample opportunity for opposition. At the same time, they considered it important to ensure that the interests of the organisation they represented were taken into account even if this was a preliminary investigation. 'Everybody knows how these things go: it is a funnel, and before you know it, a solution has been defined' said a civil servant. Finally, the flexibility demonstrated by adding extra calculations, showing the effect of alternative measures suggested by participants, has certainly helped to suspend opposition as it sent the message that the project team was listening to the concerns that were voiced.

\section{HYDRAULIC MODEL AND BLOKKENDOOS}

The hydraulic model used in IVM to calculate water levels was based on the 1-D SOBEK code (see above). Because the hydraulic calculations took some time even in SOBEK, the SOBEK model output for each individual flood reduction measure was then stored in a software package called 'Blokkendoos' (Dutch for 'box of building blocks'), developed initially for the Rhine (De Vriend \& Dijkman, 2003; Schielen \& Gijsbers, 2003; Kors, 2004; Van Schijndel, 2005). This package was subsequently adapted for the Meuse. Assuming linear superposition of the effects of different measures, the Blokkendoos can quickly evaluate the effect of combinations of measures in interactive settings.

The Blokkendoos user interface (Figure 2) comprises, in the upper half, a spreadsheet with number, location, type, hydraulic effects and cost effectiveness of all measures. In the lower half, water level graphs are shown, as well as icons representing the measures that can be switched on or off. In Figure 6 one measure has been selected, shown by the red dot. After the input of extra design discharges negotiated by the participants (see above) the three red graphs depict from top to bottom the water level at 20\%, 15 and 10\% increase in discharge. The blue graph represents the resulting water level after selecting the measure(s). The horizontal line is the target relative water level corresponding with the water level for the current design discharge, which is of course not horizontal in reality. When using the package, one of the three red lines is chosen as the active line, in Figure 5 this is the top line ( $20 \%$ increase). By clicking on a measure, the active line is lowered with the effect calculated for that measure. The active line can be made to coincide with the target line by selecting more and more measures. While in principle the Blokkendoos was a relatively simple tool to visualize effects and to compose packages of measures, in practice only well-informed experts could manipulate it. This rendered the process of selection of measures during the sessions less transparent: participants had to trust that the expert was clicking on the right buttons. 


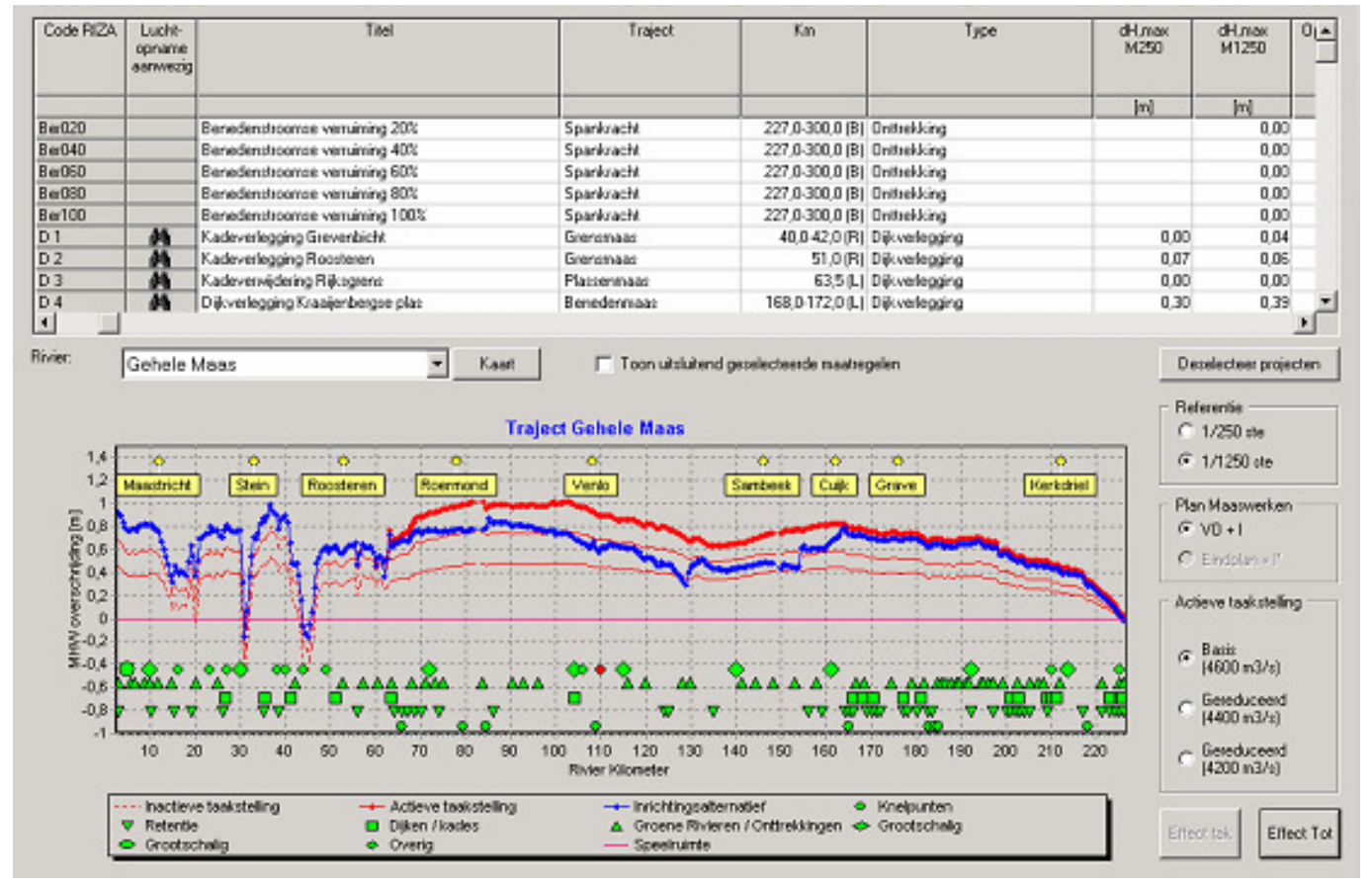

Figure 5 Screen dump of the Blokkendoos

However, a number of complications arose when the Blokkendoos was adapted for the Meuse. These made the operation of this tool even more complex. Due to the nature of the Meuse system, the effects of individual measures cannot simply be added. Consequently, the total effect calculated by the Blokkendoos was different from that calculated by the (more accurate) SOBEK model with all selected measures included. The difference could amount to $0.70 \mathrm{~m}$ on some stretches of the river, which is a figure similar to the total target water level reduction. In practice this meant that, once the target line was reached on the Blokkendoos screen, more measures had to be added in order to draw the 'real' water level down to the target, which was disappointing. Furthermore, because of this discrepancy it remained uncertain during the workshops whether the target was reached, as the SOBEK-computations took too much time to produce results at the meeting. This was dealt with by applying a correction to the target water level which corresponded with the average difference between the SOBEK model and the Blokkendoos results. Yet, this defeated somewhat the objective of providing instantaneous and interactive assessment. Some participants confused the correction with the uncertainty of the calculations (which is in the order of 10-20 cm) and remained sceptical about the usefulness of the Blokkendoos.

While the participants had no choice but to accept the need to correct the Blokkendoos results, they did challenge the contents in another way. The number of measures that were needed depended on the implementation of other plans for adjustments to the floodplain, in particular the Maaswerken and Flemish proposals for flood risk reduction. For both of these it was not certain if and to what extent they would be realized. The target line included the effects of the official 2001 Maaswerken plans while these had not been approved yet. It did not include the effects of Flemish proposals, while calculations showed that these would possibly eliminate the need to undertake anything on the Dutch side of the river, at all. Although the project team acknowledged that this problem reflected the reality of planning for an uncertain future, the choice made to take account of full implementation attracted a lot of criticism from the participants. After some discussion, the water experts responded by implementing several versions of the Maaswerken plans in the Blokkendoos. The project team did not want to take the Flemish plans into account, saying that Dutch politics had no influence on these so the worst case scenario had to be assumed. This turned out to be a workable compromise, but it also 
caused confusion as ever more options were included and it was not always clear which one was being looked at. Nevertheless, the Blokkendoos was generally accepted as providing usable information, once basic choices such as starting situation had been discussed and agreed. The participants challenged the SOBEK calculations more seriously in the next step of the project.

At the start of the project a total of 160 potential measures were identified on the $230 \mathrm{~km}$ stretch of the Dutch Meuse (Reuber et al., 2005). When the feasibility of the proposed measures was assessed in the workshops, the participants considered many aspects in their evaluation: economic, ecological, social, aesthetic, political, technical. The selection procedure is analysed in Wesselink (2007). Many measures were rejected and many were reduced in size. After the workshops it appeared that most of the remaining measures were required to achieve the flood management target and very little choice was left. The package which looked most likely to be acceptable was composed by the experts, and SOBEK calculations were run to verify whether this package would achieve the target water level. The result was a package which included three temporary storage areas outside the floodplain, which the participants had already flagged as politically unacceptable.

Discussions about the reliability of the SOBEK model had repeatedly arisen throughout the project without leading to a conclusion. When the results of the computations of the selected package became available, the calculations were seriously challenged by the project group, in particular by a few members who appeared to have considerable expertise in this field. One of them represented a province where two temporary storage areas would have to be constructed. These participants challenged the projects' water experts on two accounts: (1) a 2-dimensional WAQUA model would yield more reliable results than the 1-dimensional SOBEK model, so WAQUA should be used to verify the calculations, and (2) the impact of the proposed measures on the tidal Meuse had not been taken into account. By going through many technical details in a separate session, the project team and the water experts managed to convince the challengers that the present study did not require the added accuracy of the 2D model. The second issue had been on the projects' agenda from the start and the necessary computations were made. The results again indicated that the temporary storage areas were necessary to achieve the water level target. All substantive possibilities to challenge the results were now exhausted. The project group and the project team drew the project to a close by finalising draft recommendations to the Deputy Minister. Still, the recommendations did not include a firm commitment to reserve the areas identified for flood management as had originally been the project's objective. Political arguments apparently overruled the expertise-based conclusions on how to meet the legally non-binding targets.

\section{DISTRIBUTED EXPERTISE AND ITS DILEMMAS}

It should be clear from the above description that project group members and workshop participants had to rapidly increase their own water expertise to be able to follow and participate in the discussions, if they did not already possess this expertise through training or professional experience. In fact, we have only explained the main topics here; many other technical terms were used and discussed that increased the need for participants to learn rapidly. With the expertise they already possessed or which they built up during the project, the participants as a group had no trouble contesting the assumptions implicit in the estimate of the design discharge. They also quickly understood the basic principles of the Blokkendoos and could ask for substantial modifications to reflect their criticism. However, they did feel that it was difficult to translate the graphs into an effect on the ground and would have preferred to see flood impacts on maps.

Coming to grips with the hydraulic model proved to be the most challenging substantive aspect of IVM. The discussions on this topic, only held in the project group and not in the workshops, rapidly developed into an exchange between the water experts and others with substantial water expertise. This led to amusing situations, such as when one of the other project group members enquired whether the river bed in his region was virtual too: he had lost the plot. Although the water experts generally managed to explain technical issues to the satisfaction of all participants, this proved too difficult for 
some project group members when the experts presented the hydraulic computations to the project group. They requested translation into simpler, politically relevant conclusions. Project group members who had water expertise were able to do this because they understood both substance and relevance. This was also the reason why water expertise was successfully contested during IVM: only because the participants as a group knew what the water experts were doing could they challenge them effectively. Even though not everybody did always understand exactly what was discussed, they did appreciate that a discussion was thought necessary by others who had more expertise.

Participants had two reasons to contest the expertise offered by the water experts. The first reason is substantive: where the challenger thinks that the quality of the water experts' work is not sufficient and should be improved for quality's sake. The early challenges to the use of SOBEK are in this category. It was common knowledge that the Maaswerken had been in serious trouble in the EIAprocedure because they had used a one-dimensional model and not a more accurate two-dimensional WAQUA model. Doubts had therefore been cast on the reliability of SOBEK so participants questioned its usability in general. However, the majority of the challenges were of the second type: arguments brought forward for political reasons. In these cases, the challenger does not agree with the assumptions or the outcomes of the calculations. Instead of setting off into a political discussion where views are discussed explicitly, competing views are explored indirectly through substantive arguments. We have discussed above how the design discharge was used to challenge the need for IVM as well as the need to set the target at such a high level. We estimate that all challenges to the design discharge figures were in the second category, as were the challenges to the options available in the Blokkendoos. The challenges to the outcomes of SOBEK in the final stages of the project also clearly belong to this category.

Although most challenges to water expertise were therefore politically motivated, it is difficult to see how the efforts to answer them substantively using water expertise could have been avoided. As long as the outcome of the computations was not clear, there was no need for those opposing temporary storage areas to enter into a head-on powering game. In the consensus-oriented culture of the Netherlands, puzzling with expertise is apparently preferable to powering by politicians. The final computations showed that temporary storage areas had to be prepared for, which was politically unacceptable: in the end water expertise was overruled by political interests.

\section{CONCLUSION: WATER EXPERTISE AS CONTESTED ARBITRATOR}

In the way the 'dilemma of expertise' (Nowotny, 2003) was played out in the IVM project, water expertise was hotly contested. However, participants did not seriously question the intrinsic relevance of water expertise nor the models and data that were used. Rather, they used their challenges to advance political arguments for changes to the project objectives or results. At the same time, water expertise was clearly indispensable. Without it, it would have been impossible to verify whether the water level target had been achieved. Although expertise on a variety of other subjects was employed in the IVM project, only water expertise could provide the ultimate arbiter to check whether the flood management targets were achieved, in the shape of a hydraulic model, trumping other evaluation procedures that were employed (Wesselink, 2007).

The dominance of flood management targets over other objectives (esp. ecological and aesthetic) was also found by Meijerink (2004) in the spatial planning process to implement the Room for the River policy along the Rhine. He suggested two principal reasons. First, the flood management targets are not subject to negotiation because they are prescribed by law. This was more or less also the case in IVM, although the design discharge could be challenged there because many assumptions had to be made about an uncertain future. Second, in fulfilling this objective the Ministry of Transport, Public Works and Water Management is not inclined to spend large sums of money for other purposes, such as ecological restoration or spatial quality enhancement. Although it does not have as much budget as it would like, it is still relatively wealthy compared with the Ministry of Housing, Spatial Planning and the Environment. The latter Ministry would be expected to co-finance projects that achieve other 
objectives, which it may not be able to. Because of its larger budget, the Ministry of Transport, Public Works and Water Management can more easily impose its interests on project plans which are meant to be a cooperation with other Ministries.

From our analysis of IVM we conclude that, in spite of the ecological and spatial turns in water management at the policy level, at the implementation level flood management is still very much a water experts' affair. Even though they now collaborate with other experts in order to produce politically acceptable results, the main criterion is the fulfilment of hydraulic conditions, and water expertise provides the ultimate arbiter to judge whether targets have been achieved. Yet, in IVM political considerations trumped all substantive expertise, because in this instance water expertise did not have any backing from the law: the legal requirement does not apply to these preparations for an uncertain future. When there is a legal requirement to implement flood measures, as is the case for the Maaswerken and in the current planning procedures to implement the Room for the River policy, water expertise does have a role as ultimate arbiter. It has lost some influence in determining exactly which measures should be taken, although not as much as would seem from the ecological and spatial turns: the Ministry of Transport, Public Works and Water Management relative budgetary strength, backed by strong economic interests, gives it means to exert considerable influence on the plans that are produced. Water experts and water expertise remain indispensable, though contested for political as well as substantive reasons.

\section{REFERENCES}

Berger, H.E.J., 2002. Flow Forecasting for the river Meuse. PhD Thesis. Faculty of Civil Engineering, Delft University

Bijker, W., 2002. The Oosterschelde Storm Surge Barrier. A Test Case for Dutch Water Technology, Management, and Politics. Technology and Culture, 43 (3): 569-584.

Bruijn, K. M. de and Klijn, F., 2001. Resilient Flood Risk Management Strategies. Proc. XXIX IAHR Congress, Beijing 2001.

Collins, H. M. and Evans, R., 2002. The Third Wave of Science Studies: Studies of Expertise and Experience, Social Studies of Science, 32 (2) 235-296.

De Vriend, H. J, and Dijkman, J. P. M., 2003. A New Method of Decision Support to River Flood Management, Proceedings of the 1st International Yellow River Forum Vol. III, 21-24 October 2003, Zhengzhou, China.

Disco, C., 2002. Remaking 'Nature': The Ecological Turn in Dutch Water Management Science. Technology \& Human Values, 27 (2) 206-235.

Flyvbjerg, B., 1998. Rationality and Power: Democracy in Practice. University of Chicago Press.

Gerretsen, J.H., 2009, Flood level prediction for regulated rain-fed rivers. PhD thesis University of Twente

Goudriaan, J., van Leussen, W., Boot, U., de Wit, M., van Winden A., Ogink, H., Barneveld, H.J., Kwadijk, J., Passchier, R., Peerboom, J., de Bijl, J., Wijbenga, A., 2003. Klimaatverandering in het Maasstroomgebied - een verkenning van mogelijkheden voor afvoerreductie. In: Integrale Verkenning Maas [Integrated Assessment of the River Meuse] Advice, report and background-information (cd rom). Ministry for Transport, Public Works and Water Management, The Hague, The Netherlands.

Hoppe, R. (in prep.) The Governance of Problems. Puzzling, Powering, Participation. Manuscript. 
Kors, A., 2004. The DSS 'Planning Kit' and Its Application in the Spankracht Study. Lowland Technology International, 6 (2).

Leeuwis, C., and Van den Ban, A., 2004. Communication for Rural Innovation: Rethinking Agricultural Extension. Blackwell Science Ltd., Oxford.

Lintsen, H., 2002. Two Centuries of Central Water Management in the Netherlands. Technology and Culture, 43 (3): 549-568.

Meijerink, S., 2004. Rivierbeheer als leerproces: een tussentijdse evaluatie van het procesontwerp voor de PKB Ruimte voor de Rivier. Bestuurswetenschappen, 5 406-427

Ministerie van V\&W, 2001, Hydraulische Randvoorwaarden primaire waterkeringen 2001 [Hydraulic criteria for primary flood defenses 2001]

Ministerie van V\&W, 2003a. Integrale Verkenning Maas [Integrated Assessment of the River Meuse] Advice, report and background-information (cd rom). Ministry for Transport, Public Works and Water Management, The Hague, The Netherlands.

Ministerie van V\&W, 2003b. Het SOBEK-model IVM- 2001 Achtergronden bij de totstandkoming van de basisschematisatie. [The SOBEK model. Background information on the basic schematisation.] Integrale Verkenning Maas Rapport IVM-R-03

Nowotny, H., 2003. Dilemma of Expertise. Democratising Expertise and Socially Robust Knowledge. Science and Public Policy, 30 (3) 151-156

Pfister, L., Kwadijk, J., Musy, A., Bronstert, A. and Hoffman, L., 2004. Climate change, land use and runoff prediction in the Rhine-Meuse basins River Research and Applications 20: 229-241

Reuber, J., Schielen, R. and Barneveld, H. J., 2005. Preparing a River for the Future - The River Meuse in the Year 2050. Floods, from Defence to Management: Symposium Proceedings of the 3rd International Symposium on Flood Defence, Nijmegen, the Netherlands, 25-27 May 2005 Eds Van Alphen J, Van Beek E, Taal M (Taylor \& Francis, Abingdon)

Reuber, J., Schielen, R. and Barneveld, H. J., 2006. Die Maas im 21. Jahrhundert - Integrale Lösungsansätze zur Hochwasserproblematik. Wasserwirtschaft 6 28-33

Reuss, M., 2002. Learning from the Dutch: Technology, Management, and Water Resources Development. Technology and Culture, 43 (3).

Schielen, R. M. J. and Gijsbers, P. J. A., 2003. DSS-large Rivers: Developing a DSS under Changing Societal Requirements. Physics and Chemistry of the Earth, 28 (2003) 635-645.

Silva, W., Klijn, F. and Dijkman, J., 2001. Room for the Rhine Branches in the Netherlands; What the research has taught us. WLIDelft Hydraulics: Delft; RIZA: Arnhem. Delft Hydraulics report R3294; RIZA report 2001.031.

Staatsblad, 2006. Wet op de waterkering [Law on water defence works].

Tol, R. S. J., van der Grijp, N., Olsthoorn, A. A. and van der Werff, P. E., 2003. Adapting to Climate: A Case Study on Riverine Flood Risks in the Netherlands. Risk Analysis, 23(3) 575-583.

Van der Meulen, M. J., Rijnveld, M., Gerrits, L. M., Joziasse, J., van Heijst, M. W. I. M. and Gruijters, S. H. L. L., 2006. Handling Sediments in Dutch River Management: The Planning Stage of the Maaswerken River Widening Project . Journal of Soils and Sediments, 6 (3) 163 - 172. 
Van Hemert, M., 2004. Science and Policy in One. Interdisciplinarity and Policy Orientation in River Studies in the Netherlands. 4S/EASST Conference 2004, 25-28 August 2004, Paris.

Van Schijndel, S. A. H., 2005. The Planning Kit, a Decision-making Tool for the Rhine Branches. Proc. 3rd Int. Sym. Flood Defence 25-27 May 2005, Nijmegen, the Netherlands.

Waterforum online, 2005a. Vrijling: Eindelijk weer discussie over overstromingsrisico's. Waterforum online newsletter 1 Januari 2005 .

Waterforum online, 2005b. Experts halen overstromingsbeleid overheid onderuit. Waterforum online newsletter 3 March 2005.

Waterforum online, 2006. Rijk moet zich houden aan eigen normen bescherming hoogwater. Waterforum online newsletter 12 October 2006.

Waterforum online, 2007. Watersector dringt aan op snelle en concrete uitvoering Watervisie.

Waterforum online newsletter 22 November 2007.

Waterforum online, 2008. Hoogwaterexpert Matthijs Kok: Kans op slachtoffers bij watersnood moet omlaag. Waterforum online newsletter 19 Juni 2008.

Wesselink, A. J., Reuber, J., \& Krol, M. S., 2006. Anticipating climate change: knowledge use in participatory flood management in the river Meuse. European Water, 15/16 3-13. European Water Resources Association http://ewra.net/ew/issue_15-16.htm

Wesselink, A. J., 2007. Integration of Interests and Expertise in the Adaptation to Climate Change in the Netherlands. Proceedings International Conference on Adaptive and Integrated Water Management, 12-15 November 2007 Basel. http://www.newater.uos.de/caiwa/

Wesselink, A. J., Bijker, W. E., De Vriend, H. J. and Krol, M. S., 2007. Dutch Dealings with the Delta. Nature \& Culture, 2 (2) 188-209.

Wiering, M. A. and Driessen, P. P. J., 2001. Beyond the Art of Diking: Interactive Policy on River Management in the Netherlands. Water Policy, 3 283-296.

Wit, M.J.M. de, Warmerdam, P.M.M., Torfs, P.J.J.F., Uijlenhoet, R., Roulin, E., Cheymol, A., Deursen W. van, Walsum, P. van, Ververs, M., Kwadijk, J., Buiteveld, H., 2001. Effect of climate change on the hydrology of the river Meuse. NRP report 410200 090. Dutch National Research Programme on Global Air Pollution and Climate Change. NRP, De Bilt 